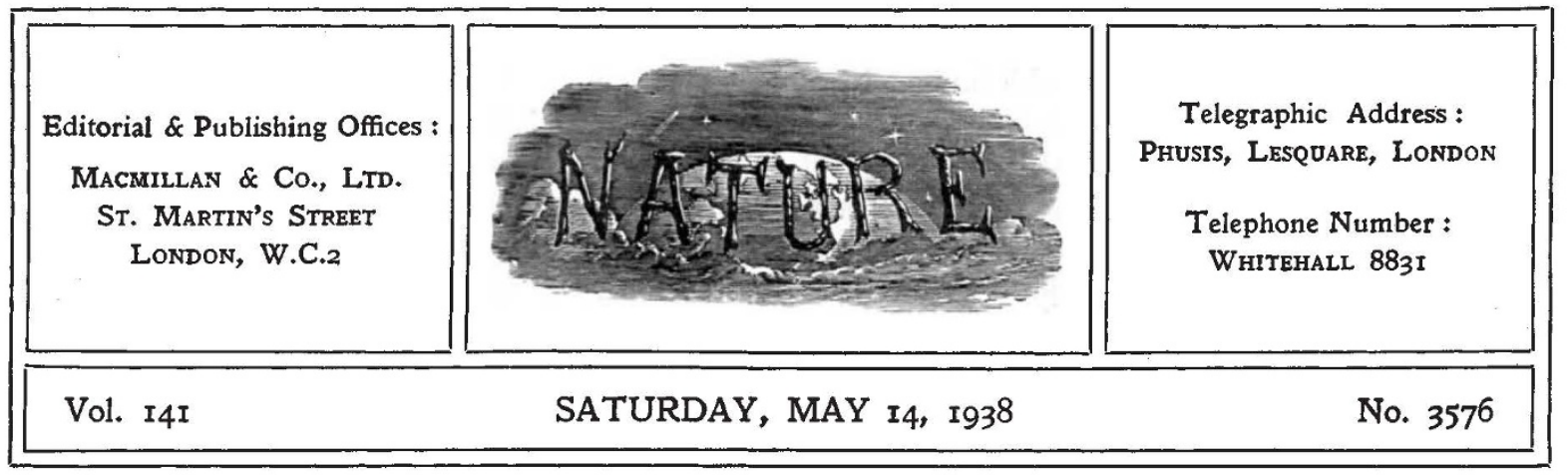

\title{
Physical Fitness at Universities
}

$\mathrm{T}$ HOSE Englishmen-unfortunately still very few-who are acquainted with the universities of Canada and the United States, have long had cause for astonishment, indeed for shame, at the way in which the universities of Great Britain have lagged behind those of America in their care for the health and fitness of their students. In those countries at any rate, it cannot be suggested that the desire to produce a healthy population is a sign of latent militarism or of any peculiar brand of politics. To an American or Canadian student—or professor-visiting Great Britain, it seems incredible that in most of our universities there is no medical examination whatever, either at entry or later on, no organized system (voluntary or compulsory) of physical exercise, little provision (except in a few privileged places) for healthy recreation 'in the spare half-hour', no arrangement to provide medical or surgical advice or treatment when required.

A wider knowledge of our deficiencies in this respect, and perhaps a stimulus to make them good, is given by a very timely pamphlet, "Student Health", recently issued by the National Union of Students.* In this pamphlet the need of student health services and of greater facilities for healthy exercise and recreation is discussed, the services and facilities existing in the United States, in Canada, in Germany and in Sweden are described, an account of what is already being done, or is contemplated, in the universities of Great Britain is set out, and a 'minimum policy' for the future is proposed.

The causes of this neglect are various and to some degree, at least, a matter for speculation: the medieval view, based upon a false antithesis

* Student Health : the Report of an Enquiry into University Health Services by the National Union of Students. Pp. 104. (London: National Union of Students, 1938.) of mind and body, that the universities exist solely for the training of the intellect; a superstitious horror of anything which might savour of organization, discipline or compulsion in personal affairs; a belief in the magic of laissez-faire ; the dominant position in public life of Oxford and Cambridge, where the colleges exert a parental influence, where most of the students are not so poor, and where games and recreations are much easier to get ; indifference; and a fear that students themselves might not co-operate. The last cause at least is removed by the publication of this pamphlet on behalf of the students themselves. It is peculiarly timely because, unknown to its writers, a new movement was already under way and that movement will be given greater confidence and strength by the knowledge that the National Union of Students is openly and emphatically sympathetic. The committee of the Union which discussed the matter "was struck with the fantastic lack of attention there had been in this country to scientific methods of physical education". "It became more and more impressed with the importance of preventive as well as curative methods". The systems in other countries, it found, "indicate a very general acceptance by the universities of a great measure of responsibility for the physical as well as the intellectual wellbeing of their students, a responsibility which is still to a large extent shirked by the universities of Great Britain".

In the autumn of 1937, the National Fitness Councils for England and Wales and for Scotland invited the University Grants Committee to advise on the distribution of a capital sum of $£ 230,000$ to aid the universities of Great Britain in providing urgently needed facilities for healthy recreation and for physical exercise. The sum itself is small- 
only about one tenth of the annual Treasury grant, for all purposes, to the universities-and it can do no more (it was not intended to do more) than catalyse the interest of the universities themselves and perhaps of their potential benefactors. That, however, it is beginning to do, and although the $£ 230,000$ itself cannot be spent otherwise than on facilities for healthy recreation-on gymnasia, swimming baths, squash courts and the like-it has set the universities thinking and planning, and ultimately very much more may result. In most of them-indeed if not all-voluntary medical examinations are to be instituted, lectures will doubtless be given on matters relating to health, the status of members of the staff dealing with physical training is to be raised, the co-operation of scientific and medical departments is to be sought, committees are to be formed to consider the place of student health as a proper function of a university; and probably, under the guidance of the Medical Research Council, in certain special centres, a scientific examination of the problem is to be instituted. An attempt is to be made, in fact, to give to the subject of bodily and mental health and fitness its proper university status. Those, however, who take a longer view will realize that it is not merely 'student health' as such which is to be aimed at, but--through the universitiesthe intelligent and conscious application of a new biological outlook on human beings, an outlook intended ultimately to affect the entire com. munity.

Health is a positive thing, namely, living up to the best powers of the individual. It is not merely absence of obvious diagnosable disease. As a matter of fact, however, even among students, disease is common enough. A professor in a medical school writes :

"Recently there have come within my notice four students with mild or severe mental trouble, three cases of early tuberculosis, and a host of minor ailments, such as trouble with hearing, vision and teeth, tonsils, colds, influenza, muscular pains, skin diseases, lassitude, anæmia, and not so very infrequently fears about health."

What is true of medical students is just as truethough not perhaps so easily realized-of others. To recognize disease, or minor ailments, or chronic under-nutrition, or mental trouble, or anything lowering the level of happiness, fitness and usefulness in university students, and to provide means of improvement, are important enough. Even more important, however, in the long run, is to send out steadily. into the community a stream of intelligent and keen young people who have learned, even in a minor way, what a health service can do for them and their friends, and how necessary it is to the happiness and well-being of the people.

Medicine at present consists too largely of the diagnosis and treatment of obvious disease, often when it is too late for complete health ever to be restored. Hospitals are crowded and only urgent cases can be considered. Human biology must take a much wider view than this of its duties and opportunities. Adequate nutrition, in quantity and quality, exercise suited to the needs and powers of the individual, healthy recreation, a sane outlook on bodily functions-not disregarding sex and reproduction-guidance and help in mental and emotional difficulty, the profitable use of holidays and leisure, all these require an educated public opinion. How better. may that educated opinion be built up than by giving to those who pass through the universities some personal appreciation and understanding of the part which an adequate health service, taking account of all such factors and employing all the resources of science, can play in promoting the well-being of those whom it reaches?

\section{Protection of Ancient Monuments in Britain*}

$\mathrm{T}^{\mathrm{H}}$ HE recently issued list of monuments in England, Wales and Scotland now protected under the Ancient Monuments Acts contains the names of more than five thousand monuments. These are of all kinds from prehistoric camps, stone circles, and barrows to the remains of abbeys, Ancient Monuments of Great Britain: List of Monuments to
December 31, 1937, prepared by the Commissioners of Works. Pp. December 31, 1937, prepared by the Commissioners of Wor
101. (London: H.M. Stationery Office, 1938.) 18. 6d. net. castles, bridges and even relatively modern buildings. Three hundred and twenty-five monuments were added to the list in 1937. Especially noteworthy among the additions are Bewcastle Roman fort, St. Alban's Gatehouse, with its archway and turrets, Reigate old town hall, which it had been proposed to demolish, the remains of the palace of Archbishop Roger at York, dating from the 